\title{
IMPLEMENTASI STRATEGI RECIPROCAL TEACHING BERORIENTASI COOPERATIVE LEARNING UNTUK MENINGKATKAN HASIL BELAJAR SISWA PADA MATERI POKOK REAKSI REDOKS DI SMA NEGERI 11 SAMARINDA
}

\author{
Dewoto Sukisnadi ${ }^{1)}$ \\ Sri Poedjiastoeti ${ }^{2)}$ \\ Suyatno ${ }^{2)}$ \\ 1) SMA Negeri 1 Samarinda \\ 2) Program Pascasarjana Universitas Negeri Surabaya \\ sdewoto@yahoo.com
}

\begin{abstract}
This research was aimed to implement reciprocal teaching strategy of cooperative learning oriented to improve students' learning outcome on redox reaction topic at SMAN 11 Samarinda. This research was conducted at SMAN 11 Samarinda involving 39 tenth grade students using one group pre-test-post-test design. The result of this research gave some information as follows; lesson plan, student's book, and worksheets were categorized as good, and students' achievement test was valid. Readability levels of the student's book and worksheet showed that the content and the design were interesting to the students. Realization of lesson plan was generally categorized as good. The dominant students' activities were discussion in making questions from reading materials and answering it and to report it in form of class presentation. Students responded positively to the learning process. Cognitive learning outcome showed that $90 \%$ of the students reached the mastery learning with mean score of 87,3 and mean gained score of 0.7 and was categorized as high. The students' social skills learning outcome (giving opinion, being good listeners, and questioning) was generally categorized as very good. The obstacles found in the learning process was that in the beginning students were unfamiliar with reciprocal teaching strategy and cooperative learning model. Therefore, continuous practices and supervision were required in order that the teaching process could be conducted as the time allocated on lesson plan. Based on the results, it was concluded that the implementation of reciprocal teaching strategy of cooperative learning oriented on redox reaction topic is effectively implemented to improve students' cognitive and social skills learning outcome.
\end{abstract}

Keywords: Reciprocal teaching, cooperative learning, redox reaction, cognitive learning outcome, social skill.

\begin{abstract}
Abstrak: Penelitian ini bertujuan mengimplementasikan strategi reciprocal teaching berorientasi cooperative learning untuk meningkatkan hasil belajar siswa pada materi pokok reaksi redoks di SMA Negeri 11 Samarinda. Penelitian dilakukan pada 39 siswa kelas X SMA Negeri 11 Samarinda dengan menggunakan desain one group pretest-posttest design. Hasil penilaian RPP, Buku Ajar Siswa dan LKS berkategori baik, sedangkan tes hasil belajar (THB) berkategori valid. Hasil penilaian keterbacaan Buku Ajar Siswa dan LKS menunjukkan bahwa isi dan penampilan menarik bagi siswa. Keterlaksanaan RPP secara umum dalam kategori baik. Aktivitas siswa yang dominan adalah berdiskusi dalam membuat pertanyaan dari bahan bacaan sekaligus jawaban (questioning) dan mengkomunikasikan informasi dalam bentuk presentasi. Siswa memberikan respon positif terhadap pembelajaran yang diterapkan. Hasil belajar kognitif produk berupa ketuntasan individual siswa sebesar 90\% dengan nilai rata-rata 87,3 dan gain score rata-rata 0,7 dengan kriteria tinggi. Hasil belajar keterampilan sosial siswa (berpendapat, menjadi pendengar yang baik, bertanya) memperoleh skor rata-rata dengan kategori sangat baik. Kendala yang ditemui adalah pada awal siswa belum terbiasa dengan pengalaman belajar yang menggunakan strategi dan model pembelajaran yang diterapkan. Latihan dan bimbingan perlu dilakukan terus menerus agar pembelajaran berlangsung baik dan sesuai dengan alokasi waktu yang tersedia dalam RPP. Berdasarkan hasil penelitian dan diskusinya, dapat disimpulkan bahwa implementasi strategi reciprocal teaching berorientasi cooperative learning pada materi pokok reaksi redoks dapat terlaksana secara efektif untuk meningkatkan hasil belajar kognitif dan keterampilan sosial siswa.
\end{abstract}

Kata-kata kunci: Reciprocal teaching, cooperative learning, reaksi redoks, hasil belajar kognitif, keterampilan sosial.

\section{PENDAHULUAN}

Berdasarkan Undang-Undang Nomor 20 tahun 2003 tentang Sistem Pendidikan Nasional, Pasal 3, tujuan pendidikan nasional diantaranya adalah mengembangkan potensi peserta didik agar menjadi manusia yang berilmu, cakap, kreatif, mandiri. Visi pendidikan nasional diantaranya adalah terwujudnya sistem pendidikan sebagai pranata sosial yang kuat dan berwibawa (Rusman, 2011). Pendidikan pada hakekatnya mengandung tiga unsur, yaitu mendidik, mengajar, dan melatih. Mendidik menurut Darmodiharjo (dalam Sadulloh, 2011) menunjukkan usaha yang lebih ditujukan kepada pengembangan budi pekerti, hati nurani, semangat, kecintaan, rasa kesusilaan, ketakwaan, dan lain-lainnya. Para ahli ilmu mendidik telah bersepakat, bahwa tujuan mendidik ialah untuk mencapai kedewasaan. Mengajar berarti memberi pelajaran tentang berbagai ilmu yang bermanfaat bagi perkembangan berpikirnya, disebut juga pendidikan intelektual. Intelek anak adalah kemampuan anak berpikir dalam bidang kehidupan. Tujuan latihan ialah untuk memperoleh keterampilan tentang sesuatu (Sadulloh, 2011). 
KTSP 2006 menuntut perubahan paradigma dalam pendidikan dan pembelajaran. Salah satu perubahan paradigma pembelajaran tersebut adalah orientasi pembelajaran yang semula berpusat pada guru beralih berpusat pada siswa; semula lebih di dominasi ekspositori berganti ke partisipatori; dan sebelumnya bersifat tekstual berubah menjadi kontekstual (Trianto, 2013).

Definisi belajar dalam kamus Dictionary of Psycology (Reber dalam Syah, 2003); pertama, the process of acquiring knowledge (proses memperoleh pengetahuan); kedua, a relatively permanent change in respon potentiality which accurs as a result of reinforced practice (suatu perubahan kemampuan bereaksi yang relatif langgeng sebagai hasil latihan yang diperkuat). Pengajar bertanggung jawab untuk membina siswa-siswa dalam memecahkan persoalan yang dihadapinya seharihari, sehingga mereka betul-betul mampu mandiri dengan menggunakan fakta, konsep, prinsip dan teoriteori yang telah mereka peroleh di dalam kelas. Demikian juga mereka dapat memecahkan masalah yang diberikan guru (Yamin, 2011. Berdasarkan uraian di atas dapat disimpulkan bahwa belajar adalah proses memperoleh pengetahuan dan perubahan kemampuan bereaksi yang relatif langgeng hasil dari latihan atau pengalaman untuk memecahkan persoalan.

Mengingat arti belajar dan fungsi pengajar untuk membina siswa yang mandiri maka keterampilan proses sains perlu diberikan. Keterampilan proses sains sangat penting dipelajari dan dikuasai oleh setiap orang, agar mampu belajar mandiri, serta mampu mengeksplorasi jagad raya. Kimia yang merupakan bagian dari IPA adalah ilmu yang mencari jawaban atas pertanyaan apa, mengapa, dan bagaimana gejala-gejala alam yang berkaitan dengan komposisi, struktur dan sifat, perubahan, dinamika, dan energetika zat (Permendiknas Nomer 22, 2006).

Berdasarkan studi pendahuluan terhadap 75 siswa klas X TP 2011/2012, siswa yang mencapai ketuntasan sebanyak $40 \%$, dan tidak tuntas $60 \%$. Nilai tertinggi dan terendah yang diperoleh berturut-turut adalah 96 dan 34 . Kriteria ketuntasan minimal (KKM) untuk mata pelajaran kimia adalah 70. Berdasarkan angket yang disebarkan kepada 31 siswa kelas XI IPA TP 2012/2013, sebanyak $52 \%$ siswa berpendapat bahwa materi redoks termasuk empat materi kimia yang paling sulit di kelas X SMA. Menurut hasil pengamatan dan diskusi dengan beberapa siswa, hasil belajar siswa yang rendah bisa disebabkan oleh (1) cara belajar yang digunakan guru kurang menarik. (2) situasi belajar yang individual. (3) guru banyak menghabiskan waktu untuk menyelesaikan materi. (4) sistem komunikasi yang satu arah. (5) beberapa siswa merasa lelah karena proses pembelajaran yang cenderung menghafal.

Berdasarkan paradigma KTSP 2006 dan studi pendahuluan yang telah dilaksanakan maka perlu untuk menerapkan model cooperative learning (pembelajaran kooperatif). Model cooperative learning dikembangkan atas dasar teori konstruktivisme dan mengembangkan keterampilan sosial siswa. Pendekatan konstruktivis pada cooperative learning memudahkan siswa menemukan dan memahami konsep-konsep yang sulit (Slavin, 2003). Cooperative learning menekankan ide bahwa siswa bekerja sama dalam belajar dan bertanggung jawab atas rekan mereka dalam kelompok dan dirinya sendiri dalam proses pembelajaran (Slavin, 1995).

Cooperative learning memiliki beberapa kelebihan, di antaranya: (1) melibatkan siswa dalam kelompok kecil, (2) guru berperan sebagai fasilitator untuk jembatan penghubung kearah pemahaman yang lebih tinggi, dengan catatan siswa sendiri (Rusman, 2011). Berdasarkan penelitian Slavin (dalam Rusman, 2011) di antaranya dinyatakan bahwa cooperative learning dapat meningkatkan prestasi belajar siswa, meningkatkan hubungan sosial dan menghargai pendapat orang lain secara terbuka,

Tastan dan Boz (2009) menyatakan bahwa cooperative learning menghasilkan perolehan pemahaman dan penghilangan miskonsepsi yang lebih baik secara signifikan dibandingkan dengan pengajaran tradisional. Sementara itu menurut penelitian Pandey dan Kishore (2003) dinyatakan bahwa cooperative learning secara signifikan meningkatkan pencapaian sains siswa dibandingkan dengan metode pengajaran tradisional dan cooperative learning secara signifikan meningkatkan pengetahuan sains siswa dibandingkan dengan metode pengajaran tradisional.

Situasi pembelajaran yang mengakibatkan siswa merasa bosan dan lelah dalam mengikuti proses pembelajaran karena materi yang disajikan cenderung menghafal daripada menggali secara mandiri untuk menemukan konsep-konsep materi, perlu dicari pemecahannya dengan strategi dan metode yang tepat. Strategi belajar reciprocal teaching (pengajaran terbalik) adalah salah satu cara untuk mengatasi keadaan tersebut. Dasar pengembangan strategi reciprocal teaching adalah siswa diajarkan tentang empat strategi kegiatan yang spesifik dalam memahami suatu bacaan, yaitu: meringkas bahan bacaan (summarizing), membuat pertanyaan dan kemudian menjawabnya (questioning), mengklarifikasi istilah-istilah yang kurang dikenal (clarifying), dan memprediksi (predicting) materi yang berikutnya (Arends, 1997). Pada implementasi reciprocal teaching, guru yang awalnya memodelkan perilaku tertentu dalam proses pembelajaran, pada tahap berikutnya siswa 
mengambil peran guru tersebut dan bertindak sebagai "guru-siswa" di kelompoknya.

Menurut penelitian yang dilakukan Choo, et al. (2011) disimpulkan bahwa: (1) kelompok siswa dengan strategi reciprocal teaching memperoleh skor yang lebih baik dalam membaca teks ekspositori dibanding dengan siswa yang diajarkan menggunakan metode membaca biasa; (2) strategi reciprocal teaching secara signifikan membantu meningkatkan kinerja siswa dalam pemahaman membaca. Hasil penelitian Qohar (2009) menyimpulkan bahwa pemahaman matematis siswa secara keseluruhan di mana pembelajarannya menggunakan strategi reciprocal teaching lebih baik daripada siswa dengan pembelajaran menggunakan metode konvensional.

Uraian-uraian di atas telah memberikan penjelasan bahwa: (1) hakekat pendidikan di antaranya adalah bertujuan untuk mengembangkan pengetahuan dan kemampuan berfikir seseorang ; (2) teori konstruktivisme menekankan siswa secara aktif membangun pengetahuan di dalam benaknya sendiri melalui pengalaman sehingga menjadi bermakna; (3) cooperative learning mengarahkan siswa menemukan dan memahami konsepkonsep yang sulit melalui kerja kelompok; dan (4) strategi reciprocal teaching membimbing siswa meningkatkan kemampuan dalam memahami isi bacaan dan mengembangkan keterampilan sosial; maka peneliti mengajukan judul "Implementasi Strategi Reciprocal Teaching Berorientasi Cooperative Learning untuk Meningkatkan Hasil Belajar Siswa pada Materi Pokok Reaksi Redoks di SMA Negeri 11 Samarinda”.

\section{METODE PENELITIAN}

Penelitian ini merupakan penelitian pra eksperimental jenis one group pretest postest design yang diawali dengan pengembangan perangkat pembelajaran. Perangkat pembelajaran yang dikembangkan meliputi Rencana Pelaksanaan Pembelajaran (RPP), Buku Ajar Siswa (BAS), Lembar Kegiatan Siswa (LKS), dan kisikisi Tes Hasil Belajar Siswa (THB). Perangkat pembelajaran tersebut selanjutnya diimplementasikan pada siswa kelas X SMA Negeri 11 Samarinda.

Penelitian ini dilaksanakan di SMA Negeri 11 Samarinda Kelas X Semester genap tahun pelajaran 2013/2014 pada materi pokok reaksi redoks. Pengambilan data dilaksanakan pada bulan April s.d. Mei 2014.

Subyek penelitian adalah hasil implementasi perangkat pembelajaran strategi reciprocal teaching berorientasi cooperative learning pada materi pokok reaksi redoks, berupa: keterlaksanaan RPP, aktivitas siswa, respon siswa, hasil belajar kognitif dan keterampilan sosial. Penelitian dilaksanakan secara terbatas, sasarannya adalah 39 siswa SMA Negeri 11 Samarinda kelas X Semester 2 tahun ajaran 2013/2014.

Rancangan penelitian yang digunakan dalam implementasi perangkat pembelajaran di kelas pada penelitian ini adalah One Group Pretest-Postest Design. Langkah pertama adalah melakukan pengukuran U1 sebagai uji awal, kemudian dikenakan perlakuan sesuai dengan Rencana Perangkat Pembelajaran (RPP), dan diakhiri dengan pengkuran U2 sebagai uji akhir. Sebelum pelaksanaan penelitian, peneliti menjelaskan dan menerangkan terlebih dahulu tentang strategi reciprocal teaching yang dipadukan dengan. Rancangan tersebut dirumuskan seperti di bawah ini (Prabowo, 2011):

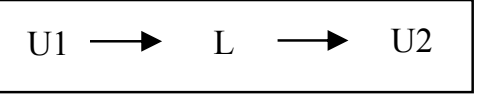

Keterangan:

U1 : Uji awal (Pretest), untuk mengetahui penguasaan siswa terhadap materi pelajaran sebelum implementasi pembelajaran.

U2 : Uji akhir (Posttest), untuk mengetahui penguasaan siswa terhadap materi pelajaran sesudah implementasi pembelajaran.

$\mathrm{L}$ : Perlakuan, implementasi pengembangan strategi reciprocal teaching berorientasi cooperative learning.

\section{HASIL DAN PEMBAHASAN}

\section{A. Hasil Pengembangan Perangkat Pembelajaran}

Perangkat pembelajaran yang dikembangkan digunakan untuk menunjang proses pembelajaran sesuai dengan materi pokok reaksi redoks kelas X.

1. Hasil Validasi Perangkat Pembelajaran

Perangkat pembelajaran yang ditelaah meliputi Rencana Pelaksanaan Pembelajaran (RPP), Buku Ajar Siswa (BAS), Lembar Kegiatan Siswa (LKS), dan kisikisi soal Tes Hasil Belajar (THB). Perangkat pembelajaran divalidasi oleh para ahli (validator) untuk memperoleh kepastian bahwa perangkat pembelajaran layak digunakan. Hasil validasi untuk RPP, BAS, dan LKS berturut-turut adalah 4,31 kategori sangat baik; 4, 21 kategori baik; dan 4,19 kategori baik. Para validator menilai pada soal THB sebanyal 19 butir soal valid, 3 butir soal cukup valid, dan 3 butir soal kurang valid. Ratarata sensitivitas butir soal sebesar 0,66 dengan kategori sensitif.

RPP yang dikembangkan disusun untuk mencapai satu kompetensi dasar, yaitu menjelaskan perkembangan konsep oksidasi reduksi dan hubungannya dengan tatanama senyawa serta penerapannya. Untuk pencapaian kompetensi dasar tersebut, disusun 10 indikator produk yang dikembangkan menjadi 25 tujuan pembelajaran. Validasi terhadap RPP yang dikembangkan, tiga validator sebagai penilai secara umum memberikan penilaian dengan kategori baik.

Penyisipan keterampilan sosial yang terintegrasi pada kegiatan pembelajaran, utamanya pada kegiatan inti, bertujuan agar pada diri siswa tumbuh nilai-nilai sosial di 
lingkungan kelas, seperti: berpendapat, menjadi pendengar yang baik, dan bertanya; dimana diharapkan nantinya dapat mengaplikasikan dalam kehidupan seharihari. Hal tersebut sesuai dengan tujuan pembelajaran kooperatif, yaitu: mengajarkan kepada siswa keterampilan kerjasama dan kolaborasi (Arends, 1997). Salah satu kelebihan pembelajaran kooperatif adalah model pembelajaran kooperatif merupakan model pembelajaran yang cukup ampuh untuk meningkatkan prestasi akademik sekaligus keterampilan sosial (Sanjaya, 2009).

Secara keseluruhan RPP sudah disusun berdasarkan panduan yang benar, baik mengenai komponen RPP, prinsip-prinsip penyusunan RPP, maupun langkah-langkah penyusunan RPP (Depdiknas, 2008a). Diharapkan penyusunan RPP yang sudah dijelaskan di atas tentunya akan memudahkan orang lain untuk memahami dan menerapkan RPP ini di kelas.

Penilaian yang diberikan oleh validator terhadap BAS rata-rata memiliki kategori baik terhadap komponen kelayakan isi, kelayakan bahasa, dan kelayakan penyajian. BAS yang dikembangkan ini disusun dengan mengacu pada panduan pengembangan bahan ajar Depdiknas agar fungsi pembuatan bahan ajar bisa tercapai (Depdiknas, 2008b).

Komponen kelayakan isi pada BAS memiliki kategori baik. Prinsip-prinsip yang dijadikan dasar dalam menentukan materi BAS adalah kesesuaian, keajegan, dan kecukupan (Depdiknas, 2008c: 5). Komponen kelayakan bahasa memiliki kategori baik, hal ini ditunjang pengggunaan bahasa yang komunikatif. Kategori baik pada komponen kelayakan penyajian dikarenakan adanya fitur-fitur yang menarik untuk dicermati dan dipahami, didukung teks, tabel, ilustrasi gambar yang berwarnawarni untuk merangsang kedalaman berfikir siswa serta memotivasi siswa agar dalam memahami suatu konsep terasa lebih sederhana dan mudah dicerna.

Terhadap ketiga aspek yang dinilai dari LKS, yaitu: format, kelayakan isi, dan bahasa; para validator secara rata-rata memberi penilaian dengan kategori baik. Kategori baik baik bisa dicapai, karena penyusunan LKS yang dikembangkan ini mengacu pada panduan pengembangan bahan ajar agar fungsi pembuatan bahan ajar bisa tercapai ajar (Depdiknas, 2008b: 19).

LKS yang dikembangkan ini sudah sesuai dengan RPP yaitu menggunakan strategi reciprocal teaching berorientasi cooperative learning. Implementasi empat kegiatan spesisik reciprocal teaching diintegrasikan ke dalam sintaks ke-4 model pembelajaran kooperatif, yaitu guru membimbing siswa dalam bekerja dan belajar.

Empat kegiatan spesifik reciprocal teaching dalam LKS sudah tertulis tahap demi tahap dan mudah dipahami. Strategi reciprocal teaching ini dipilih karena: pembaca, b) memberi pembaca peluang untuk memantau pemahaman sendiri; dan c) sangat mendukung dialog bersifat kerja sama atau diskusi (Trianto: 2013). Reciprocal teaching memberi kesempatan kepada guru untuk mengajarkan siswa keterampilan-keterampilan kognitif penting dengan menciptakan pengalamanpengalaman belajar, pada kesempatan tertentu guru memodelkan perilaku tertentu dan kemudian membantu siswa mengembangkan keterampilan-keterampilan tersebut berkat upaya mereka sendiri dengan pemberian semangat, dukungan, dan suatu sistem scaffolding (Palinscar \& Brown, 1984).

Hasil analisis sensitivitas butir soal tes hasil belajar implementasi strategi reciprocal teaching berorientasi cooperative learning menunjukkan bahwa indeks sensitivitas butir soal berharga positif, dengan rata-rata 0,66 masuk pada kategori sensitif. Indeks sensitivitas butir soal pada dasarnya merupakan ukuran seberapa baik butir soal tersebut membedakan antara peserta didik setelah dan sebelum mengikuti proses belajar mengajar. Sebaran indeks sensitivitas butir soal tes strategi reciprocal teaching berorientasi cooperative learning adalah terendah 0,3 dan tertinggi 1,0. Menurut Grounlund (1981: 266), sensitivitas butir soal bermakna semakin tinggi harga sensitivitas maka efek terhadap pembelajaran tinggi. Menurut Aiken (dalam Trianto, 2013: 242), suatu butir soal dikatakan sensitif jika memiliki indeks sensitivitas $\geq 0,3$.

\section{Hasil Keterbacaan BAS dan LKS}

Keterbacaan BAS dan LKS menggambarkan tingkat pemahaman siswa terhadap BAS dan LKS yang dikembangkan. Kegiatan observasi dilakukan untuk mengetahui keterbacaan BAS dan LKS dengan cara mengedarkan angket kepada 24 siswa. Hasil penilaian keterbacaan BAS adalah: 100\% siswa berpendapat isi dan penampilan BAS menarik, penjelasan BAS tidak ada yang sulit, dan ilustrasi/gambar BAS mudah dipahami. Sementara itu $100 \%$ siswa berpendapat isi dan penampilan LKS menarik, $83 \%$ siswa menilai penjelasan LKS tidak sulit.

Berdasarkan penjelasan di atas, secara umum BAS dan LKS yang dikembangkan dalam hal isi, penampilan, maupun uraian/penjelasannya menarik bagi siswa sehingga diharapkan BAS dan LKS tersebut dapat membangkitkan semangat belajar siswa, sesuai dengan perkembangan siswa dan persentase keterbacaannya tinggi. Hal di atas sesuai dengan syarat dikeluarkan Depdiknas bahwa bahan ajar yang baik adalah bahan ajar yang ditulis dengan menggunakan bahasa yang baik dan mudah dimengerti, disajikan secara menarik dilengkapi dengan gambar dan keterangan-keterangannya. 


\section{B. Hasil Implementasi Perangkat Pembelajaran 1. Keterlaksanaan RPP}

Pengamatan terhadap keterlaksanaan RPP dilakukan oleh dua guru kimia SMA Negeri 11 Samarinda yang bertindak sebagai pengamat. Pengamat bertugas mencatat keterlaksanaan RPP dan memberi nilai keterlaksanaan. Hasil penilaian rata-rata pada pengelolaan KBM yaitu pendahuluan, kegiatan inti dan penutup memperoleh skor dengan kriteria baik dimana semua aspek terlaksana. Demikian pula untuk pengelolaan kelas meliputi antusias siswa, antusias guru, dan waktu sesuai alokasi memperoleh skor dengan kriteria baik. Variasi skor hasil pengamatan adalah 3 dan 4 .

RPP yang dikembangkan seluruhnya berorientasikan model cooperative learning dengan strategi reciprocal teaching. Langkah-langkah reciprocal teaching diintegrasikan ke dalam sintaks ke-4 model cooperative learning. Dipilihnya model cooperative learning dan strategi reciprocal teaching agar setelah pembelajaran diperoleh ketuntasan hasil belajar siswa yang maksimal. Menurut penelitian Ofodu dan Adebayo (2011), metode think pair share dan strategi reciprocal teaching yang berorientasi pembelajaran kooperatif memiliki keunggulan dan pengaruh yang signifikan terhadap pemahaman membaca siswa dibandingkan dengan pengajaran konvensional.

Langkah implementasi reciprocal teaching yang merupakan inti dari pembelajaran ini secara umum memiliki kriteria baik. Penggalan 1 untuk semua pertemuan rata-rata skor yang diperoleh pada kegiatan: Clarifying adalah 4,0; questioning adalah 4,0; summarizing adalah 3,7 ; dan predicting adalah 4 . Pada kegiatan clarifying secara umum memiliki kriteria baik, berarti siswa sudah memahami langkah tersebut. Kegiatan summarizing secara umum memiliki kriteria baik. Kegiatan ini cukup memeras pikiran siswa dimana siswa dituntut bisa membuat intisari dari proses membaca yang sudah dilakukannya. Hal yang menarik, pada kegiatan predicting skor siswa memiliki kriteria baik dan stabil untuk setiap pertemuan karena bagi siswa kegiatan itu yang dirasakan paling mudah dilakukan ketika membaca BAS. Untuk penggalan 2 skor rata-rata siswa kurang lebih sama dengan skor pada penggalan 1. Pada pertemuan 2 tidak dilakukan pemenggalan dengan pertimbangan hanya ada satu sub pokok bahasan, yaitu menentuan reaksi redoks atau bukan reaksi redoks.

Secara umum aspek pengelolaan proses pembelajaran memiliki kriteria baik. Hal ini menunjukkan bahwa RPP yang dikembangkan sudah disusun secara baik dan proporsional sesuai dengan model pembelajaran, srategi pembelajaran, dan alokasi waktu yang disediakan. Aspek pengelolaan kelas memiliki kriteria baik, dimana siswa antusias (skor rata-rata 3,7), guru antusias (skor rata-rata 4), dan waktu sesuai alokasi (skor rata-rata 3,3). Rata-rata keseluruhan penilaian terhadap keterlaksanaan RPP berada dalam kriteria baik dengan skor rata-rata 3,91. Hal ini menunjukkan bahwa RPP yang dikembangkan telah disusun dengan baik sehingga dapat digunakan dan dilaksanakan dengan baik.

\section{Aktivitas Siswa}

Penilaian aktivitas siswa dilakukan oleh dua orang guru yang berpengalaman mengajar di kelas yang bertindak sebagai pengamat. Hasil pengamatan aktivitas siswa dinyatakan dalam persentase. Hasil pengamatan aktivitas siswa disajikan pada Gambar 1.

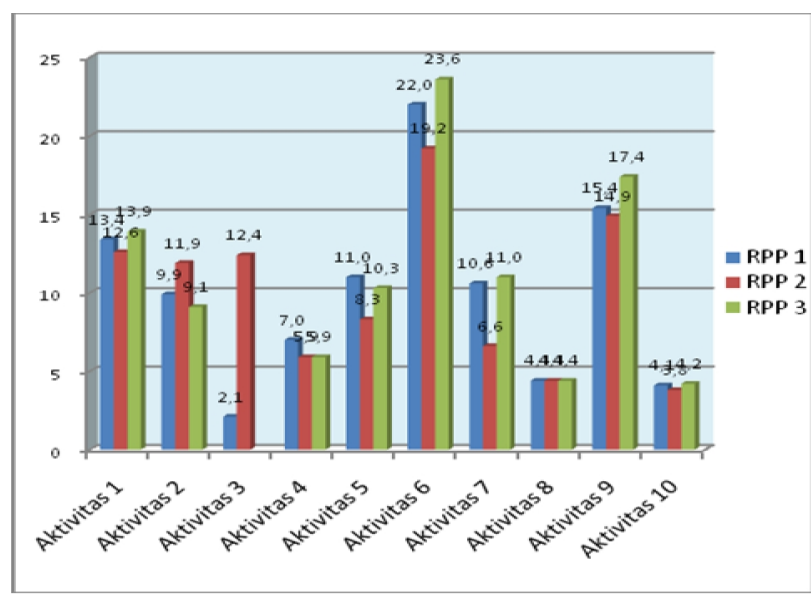

Gambar 1. Persentase Aktivitas Siswa dalam Pembelajaran

Aktivitas yang paling tinggi dilakukan oleh siswa selama pembelajaran (pertemuan 1, 2, dan 3) adalah aktivitas 6 (berdiskusi dalam membuat pertanyaan dari bahan bacaan sekaligus jawaban (questioning); aktivitas 9 (mengkomunikasikan informasi, meliputi: presentasi "guru-siswa", bertanya, dan berpendapat.); dan aktivitas 1 (mendengarkan dan memperhatikan penjelasan guru).

Aktivitas 5, 6, 7, dan 8 adalah langkah-langkah strategi reciprocal teaching, terintegrasi dalam sintaks 4 model cooperative learning. Aktivitas 6 secara khusus sebagai aktivitas siswa yang paling tinggi dalam pembelajaran bisa diterima, karena kunci keberhasilan dari pembelajaran ini adalah sejauh mana siswa bisa menuliskan suatu pertanyaan (quetioning) kemudian tahap demi tahap menuliskan jawabannya. Dipimpim ketua kelompok sebagai "guru-siswa", para siswa berdiskusi untuk membuat pertanyaan yang sekaligus membuat jawaban. Kegiatan ini memerlukan waktu lama karena siswa sedang melakukan proses asimilasi menuju ke proses akomodasi menurut teori Piaget. Siswa dituntut bisa membuat struktur kognitif yang baru untuk mengadaptasi informasi baru agar diperoleh keseimbangan. Struktur kognitif baru bisa diperoleh dengan berfikir mandiri atau berdiskusi dengan teman 
untuk memperkuat struktur kognitif yang sudah ada. Keseimbangan inilah yang melahirkan pemahaman sehingga siswa menemukan cara penyelesaian yang dituangkan dalam bentuk jawaban pertanyaan. Hal ini menunjukkan bahwa reciprocal teaching dapat memfasilitasi siswa untuk mengembangkan potensinya dalam rangka menerapkan cara belajar yang efektif.

Aktivitas 9 (mengkomunikasi informasi) diintegrasikan ke dalam sintaks 5 model cooperative learning. Kegiatan mengkomunikasikan informasi berisi presentasi oleh ketua kelompok untuk bertindak sebagai guru-siswa menggantikan guru asli yang dilanjutkan dengan tanggapan dan pertanyaan dari kelompok lain. Hasil yang diharapkan dari kegiatan ini adalah siswa lebih aktif berperan dalam pembelajaran melalui tanggapan dan pertanyaan antar siswa sehingga suasana belajar lebih hidup. Pemahaman akan diperoleh jika siswa secara aktif mengkonstruksi pengetahuannya secara mandiri dan terus menerus.

Aktivitas 1 berupa mendengarkan dan memperhatikan penjelasan guru sangat diperlukan siswa. Pembelajaran tidak akan optimal apabila tidak diarahkan oleh guru. Informasi guru sangat diperlukan mempersiapkan materi yang akan dipelajari siswa.

\section{Respon Siswa}

Hasil analisis respon siswa terhadap pembelajaran disajikan berturut-turut pada Gambar 2, 3, 4, 5, 6, 7, dan 8. Hasil pendapat siswa diberikan dalam harga persentase.

a. Ketertarikan terhadap Komponen Pembelajaran

Ketertarikan siswa terhadap komponen materi/isi pelajaran, BAS, LKS, suasana belajar, dan cara guru mengajar disajikan pada Gambar 2 berikut.

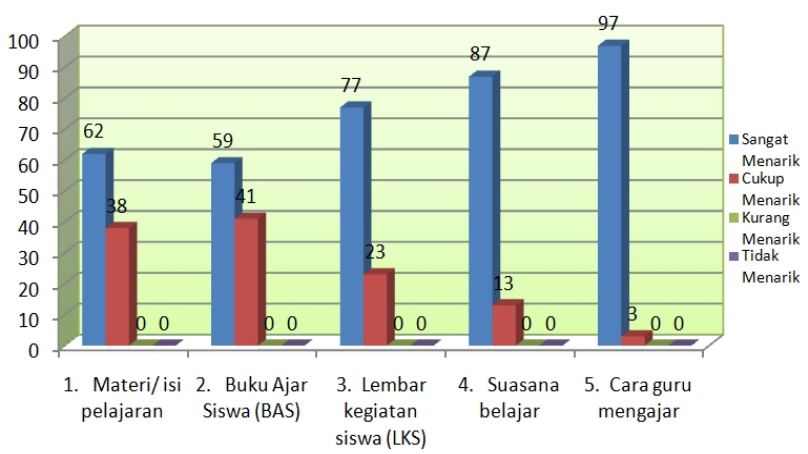

Gambar 2. Diagram Persentase Ketertarikan Siswa Terhadap Komponen.

Gambar 2 menunjukkan bahwa siswa tertarik dengan komponen-komponen pembelajaran. Persentase ketertarikan siswa yang tinggi terhadap komponenkomponen tersebut mencerminkan bahwa perangkat pembelajaran yang disusun dan pelaksanaannya dilapangan sudah sesuai dengan perkembangan kognitif siswa. Menurut Piaget (dalam Budiningsih, 2005), ciri pokok perkembangan tahap operasional formal (umur 12-
18 tahun) adalah anak sudah mampu berpikir abstrak dan logis dengan menggunakan pola berpikir "kemungkinan".

\section{b. Keterbaruan Komponen Pembelajaran}

Respon siswa terhadap keterbaruan komponen materi/isi pelajaran, BAS, LKS, suasana belajar, dan cara guru mengajar diberikan pada Gambar 2 berikut.

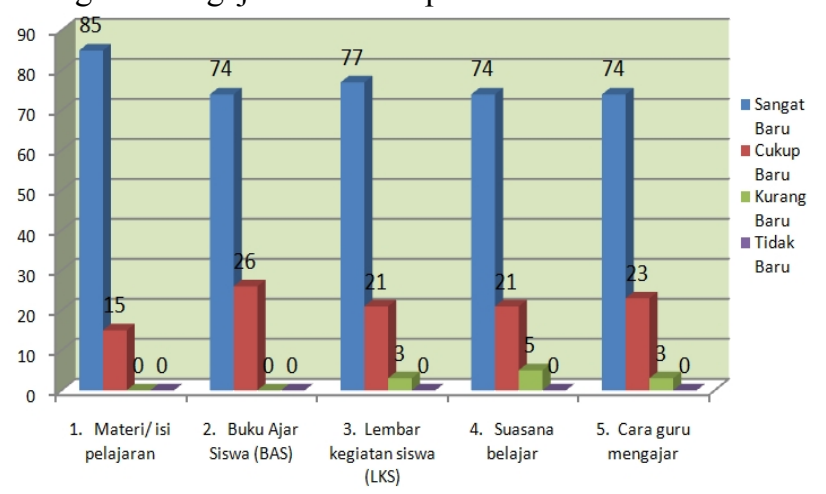

Gambar 3. Diagram Persentase Keterbaruan Komponen Bagi Siswa

Berdasarkan Gambar 3 menunjukkan bahwa siswa secara umum memberikan penilaian baru terhadap komponen materi/isi pelajaran, BAS, suasana belajar, dan cara guru mengajar.

\section{c. Kemudahan Memahami Komponen}

Kemudahan siswa dalam memahami komponen materi/isi pelajaran, BAS, LKS, suasana belajar, dan cara guru mengajar dapat dilihat pada Gambar 4 berikut.

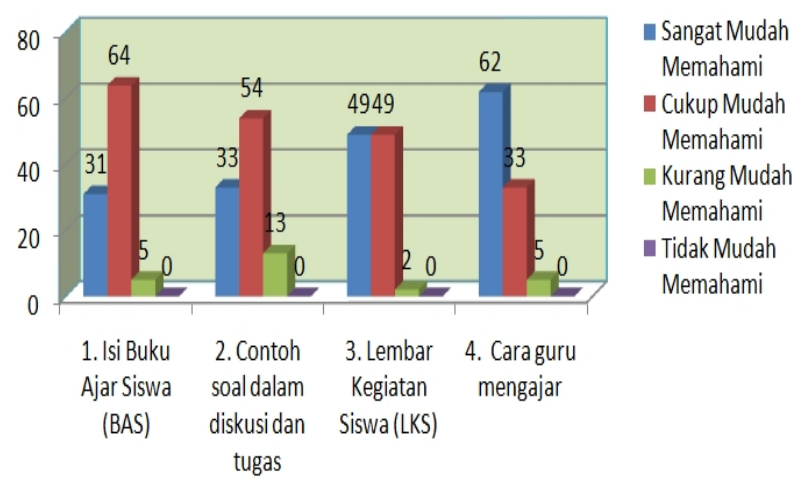

Gambar 4. Diagram Persentase Kemudahan Memahami Komponen

Berdasarkan Gambar 4, siswa umumnya memberikan penilaian dengan kategori memahami terhadap komponen-komponen pembelajaran. Isi buku ajar siswa cukup dipahami oleh siswa. Kondisi ini sangat mendukung bagi efektifitasnya proses pembelajaran.

\section{d. Kemudahan Memahami Langkah-langkah Reciprocal Teaching}

Kemudahan siswa dalam memahami langkahlangkah reciprocal teaching disajikan pada Gambar 4 berikut. 


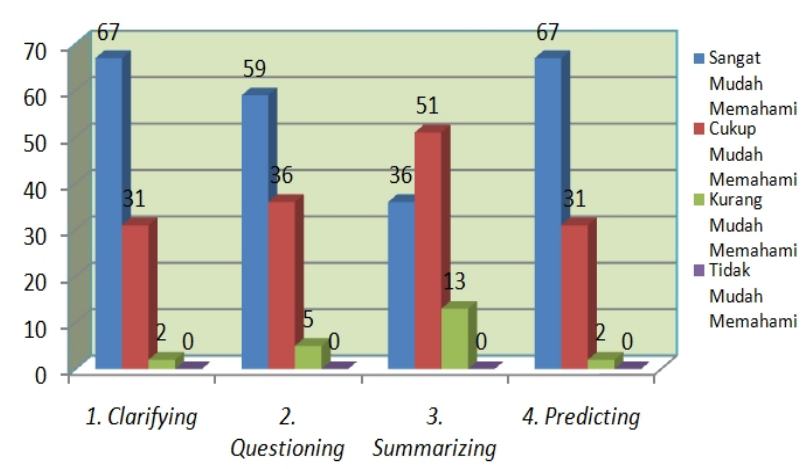

Gambar 5. Diagram Persentase Siswa Kemu-dahan Memahami RT

Berdasarkan Gambar 5, secara umum siswa memahami langkah-langkah reciprocal teaching yang dilakukan dengan cara diskusi. Persentase yang tinggi terhadap aspek mudah memahami langkah-langkah reciprocal teaching memungkinkan siswa mampu menguasai lebih banyak materi yang diberikan. Hal ini ditunjukkan dengan hasil ketuntasan belajar siswa secara klasikal adalah $90 \%$ dengan rata-rata nilai post test sebesar 87,3 .

\section{e. Minat Siswa}

Minat siswa jika implementasikan strategi reciprocal teaching diterapkan pada pembelajaran selanjutnya diberikan pada Gambar 6 berikut.

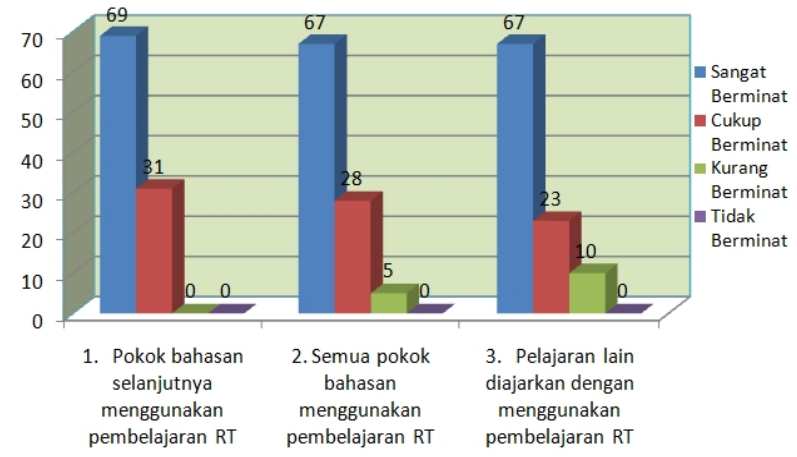

Gambar 6. Diagram Persentase Minat Siswa Terhadap Komponen

Gambar 6 menunjukkan bahwa siswa mempunyai minat yang tinggi terhadap metode pembelajaran yang sedang diterapkan yaitu strategi reciprocal teaching. Hal ini mencerminkan strategi reciprocal teaching sangat cocok diterapkan pada materi redoks klas X. Menurut Fadholi (2004), strategi reciprocal teaching cukup efektif untuk meningkatkan hasil belajar siswa dan membangkitkan minat belajar siswa.

\section{f. Kejelasan Pengajaran Guru}

Respon siswa terhadap penjelasan dan bimbingan guru saat proses pembelajaran berlangsung dapat dilihat pada Gambar 7 berikut.

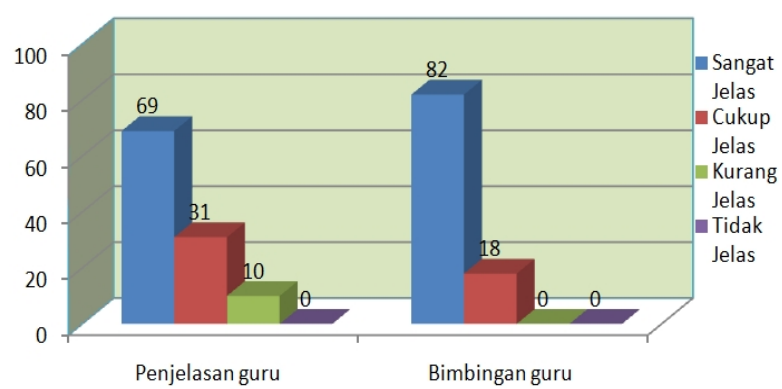

Gambar 7. Diagram Persentase Respon Siswa Pengajaran Guru

Berdasarkan Gambar 7 dapat dijelaskan bahwa rata-rata siswa menilai dengan kategori jelas ketika guru menjelaskan dan membimbing pada proses pembelajaran. Kejelasan akan bimbingan guru cukup membantu siswa dalam memahami materi yang diberikan.

\section{g. Kemampuan Memahami Soal THB}

Respon siswa di dalam memahami soal-soal THB dapat dilihat pada Gambar 8 berikut.

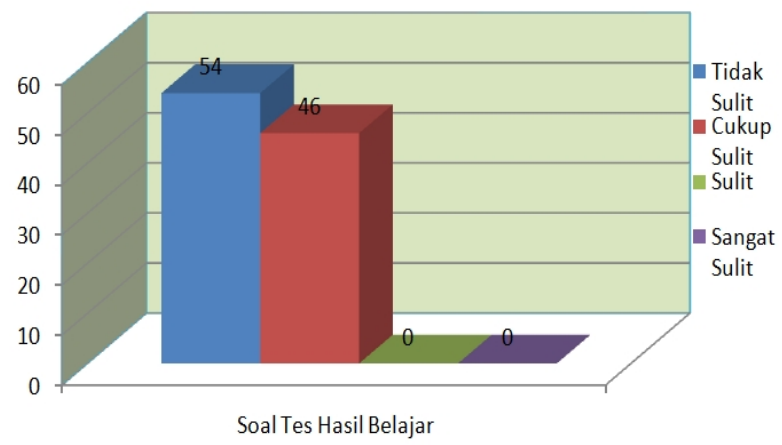

Gambar 8. Diagram Persentase Kesulitan Siswa Menjawab Soal THB

Berdasarkan Gambar 8, secara umum siswa tidak sulit untuk memahami soal THB. Hal ini menunjukkan bahwa proses pembelajaran yang sudah diterapkan membuat siswa lebih mudah untuk menjawab soal-soal tes hasil belajar. Respon siswa ini didukung oleh hasil nilai rata-rata siswa pada post test dimana 90\% siswa sudah mencapai nilai KKM (KKM sekolah=70).

Kesimpulan dari hasil diskusi tentang respon siswa adalah secara umum siswa menilai positif terhadap model pembelajaran yang diterapkan. Siswa tertarik dan sangat berminat terhadap model pembelajaran yang diterapkan. Hasil dari model pembelajaran yang diterapkan menjadikan siswa tidak sulit untuk menjawab soal-soal tes hasil belajar.

\section{Hasil Belajar Kognitif}

Sesuai ketentuan, ketuntasan hasil belajar siswa secara individual didasarkan pada standar ketuntasan minimal (KKM) yang ditetapkan oleh pihak sekolah. KKM kimia di SMA Negeri 11 Samarinda adalah 70. 
Berdasarkan hasil pretest semua siswa mendapat kriteria tidak tuntas, sedangkan pada nilai posttest dapat diketahui bahwa sebanyak 35 siswa yang mendapatkan skor $\geq 70$ berarti tuntas dan hanya 4 siswa yang mendapatkan skor $<70$ berarti tidak tuntas. Skor rata-rata posttest adalah 87,3. Empat orang siswa yang belum tuntas selanjutnya diberikan remedial hingga tuntas. Berdasarkan data, ketuntasan klasikal terpenuhi karena terdapat $\geq 85 \%$ siswa dalam satu kelas (35 siswa dari 39 siswa) tuntas (90\%). Skor peningkatan (Gain) rata-rata sebesar 0,7 termasuk kategori tinggi.

Ketuntasan belajar siswa sebagai hasil dari suatu proses pembelajaran disebabkan oleh beberapa faktor, diantaranya: (1) tersedianya perangkat pembelajaran yang baik, meliputi: RPP, BAS, LKS, dan Kisi-kisi soal; (2) Kemudahan guru melaksanakan skenario RPP sehingga pembelajaran berlangsung baik, hal ini didukung data bahwa sintaks-sintaks dalam RPP dapat terlaksana dengan kriteria baik; (3) aktivitas siswa, hal ini didukung aktivitas siswa yang paling tinggi adalah langkah questioning dan mengkomunikasikan informasi. Piaget dan Vigotsky menekankan adanya hakekat sosial dari belajar, keduanya juga menyarankan untuk menggunakan kelompokkelompok belajar dengan kemampuan anggota kelompok yang berbeda-beda untuk mengupayakan perubahan pengertian atau belajar ( Nur, 2008).

Implementasi strategi reciprocal teaching berorientasi cooperative pada pembelajaran dapat meningkatkan ketuntasan hasil belajar siswa. Hal ini sesuai dengan penelitian Wilujeng (1999) yang menyimpulkan bahwa setelah menerapkan pendekatan reciprocal teaching dalam pembelajaran Fisika, hasil belajar siswa untuk pokok bahasan tektonik lempeng terdapat peningkatan baik produk maupun proses. Hasil penelitian Sisovic (2001) juga menunjukkan bahwa cooperative learning berhasil mengembangkan tingkat pemahaman siswa pada konsep hidrolisis garam.

Berdasarkan ketuntasan indikator, sebanyak 9 dari 10 indikator tuntas dengan skor rata-rata tuntas $86,6 \%$; berarti ketuntasan indikator secara klasikal sebesar 90\%. Sebuah indikator dikatakan tuntas apabila proporsi skor siswa $\geq 0,75$ (75\%). Selanjutnya untuk satu indikator yang tidak tuntas dilakukan remedial sehingga tuntas.

Ketuntasan indikator sebelum dilakukan pembelajaran strategi reciprocal teaching (pretest) tidak ada satupun yang tuntas. Setelah dilakukan pembelajaran strategi reciprocal teaching ketuntasan indikator meningkat menjadi rata-rata skor $86,6 \%$ (post test). Dari sisi ketuntasan indikator, hasil belajar siswa juga meningkat ditunjukkan dengan perolehan rata-rata gain score sebesar 0,8 yang berada pada kriteria tinggi. Setelah pembelajaran yang mengimplemen-tasikan strategi reciprocal teaching ternyata bisa meningkatkan hasil belajar siswa, baik ketuntasan individual maupun klasikal. Kondisi ini juga didukung oleh data dimana secara umum kemampuan siswa dalam menerapkan langkah-langkah strategi reciprocal teaching memiliki kriteria sangat baik.

\section{Hasil Penilaian Kemampuan Menerapkan Langkah-langkah Reciprocal Teaching}

Langkah-langkah reciprocal teaching yang dikembangkan adalah clarifying, questioning, summarizing, dan predicting. Hasil penilaian terhadap kemampuan siswa dalam menerapkan langkah-langkah reciprocal teaching disajikan pada Tabel 8 berikut.

Tabel 8. Hasil Penilaian Rata-rata Kemampuan Siswa Menerapkan Reciprocal Teaching.

\begin{tabular}{|c|c|c|c|c|c|c|c|c|c|}
\hline \multirow{2}{*}{ No } & \multirow{2}{*}{ Pt } & \multicolumn{2}{c|}{$\boldsymbol{C l}$} & \multicolumn{2}{c|}{$\boldsymbol{Q u}$} & \multicolumn{2}{|c|}{$\boldsymbol{S u}$} & \multicolumn{2}{|c|}{$\boldsymbol{P r}$} \\
\hline & & Sk & Kt & Sk & Kt & Sk & Kt & Sk & Kt \\
\hline 1 & Pt-1 & 3,7 & SB & 3,5 & SB & 3 & B & 4 & SB \\
\hline 2 & Pt-2 & 3,9 & SB & 3,6 & SB & 3,7 & SB & 4 & SB \\
\hline 3 & Pt-3 & 4 & SB & 3,5 & SB & 4 & SB & 4 & SB \\
\hline Rata-rata & 3,9 & SB & 3,5 & SB & 3,6 & SB & 4,0 & SB \\
\hline
\end{tabular}

\section{Keterangan:}

$\mathrm{Pt}=$ Pertemuan, $\mathrm{Cl}=$ Clarifying, $\mathrm{Qu}=$ Ouestioning, $\mathrm{Su}=$ Summarizing $\mathrm{Pr}=$ Predicting, $\mathrm{Sk}=$ Skor, $\mathrm{Kt}=$ Kategori, $\mathrm{SB}=$ Sangat Baik, $\mathrm{B}=$ Baik

Mengamati Tabel di atas, kemampuan siswa dalam komponen predicting rata-rata memperoleh skor 4 dengan kriteria sangat baik. Hal kedua yang nampaknya bisa dilakukan siswa adalah clarifying yang memperoleh skor rata-rata 3,9. Faktor yang sangat membantu pada aspek ini adalah siswa sudah terlebih dahulu mengerjakan LKS di mana dengan cara mengerjakan LKS siswa memperoleh pengalaman dalam melaksanakan dan menuliskan clarifying. Rata-rata siswa dalam melaksanakan clarifying memperoleh kriteria baik dan sangat baik.

Langkah questioning kegiatannya adalah membuat pertanyaan sekaligus membuat jawaban pertanyaan atau penyelesaian. Proses membuat jawaban adalah suatu proses kognitif dari asimilasi menuju proses akomodasi. Jawaban pertanyaan bisa dilakukan siswa apabila secara khusus siswa sudah memahami konsep-konsep yang di baca. Pemahaman konsep akan diterima siswa apabila dalam proses asimilasi menuju akomodasi terjadi keseimbangan (ekuilibrasi). Skor rata-rata siswa dalam questioning dan summarizing memiliki kategori sangat baik. Kategori sangat baik yang diperoleh siswa dalam menerapkan reciprocal teaching sangat membantu untuk mencapai ketuntasan hasil belajar.

\section{Hasil Pengamatan Keterampilan Sosial Siswa}

Keterampilan sosial yang diamati dalam pembelajaran ini meliputi bertanya, menjadi pendengar, dan berpendapat. Hasil Penilaian rata-rata keterampilan sosial siswa pada setiap pertemuan pada aspek 
berbendapat, menjadi pendengar yang baik, dan bertanya berturut-turut adalah 3,4 kategori sangat baik; 3,7 kategori sangat baik; dan 3,6 kriteria sangat. Skor yang diperoleh siswa bervariasi dari 2 sampai dengan 4 .

Keterampilan sosial siswa pada aspek berpendapat rata-rata pada kategori sangat baik. Selama proses pembelajaran ada siswa yang pada awalnya memperoleh skor 2 (kategori memerlukan perbaikan) dan memperoleh skor 3 (kategori memuaskan). Hal ini bisa dipahami karena bagi siswa pembelajaran ini adalah baru, termasuk model pembelajaran dan strategi yang digunakan.

Keterampilan sosial dalam aspek menjadi pendengar yang baik, umumnya para siswa memperoleh kriteria sangat baik atau memuaskan, tidak ada siswa yang memperoleh skor 2. Skor yang diperoleh siswa pada aspek bertanya umumnya pada kriteria sangat baik, walapun ada beberapa siswa memperoleh skor 3 (memuaskan) atau 2 (memerlukan perbaikan). Dukungan teman sekelompok dan bimbingan guru tahap demi tahap diperlukan untuk mengatasi permasalahan ini. Secara umum keterampilan sosial siswa memiliki kategori sangat baik.

\section{PENUTUP}

\section{Simpulan}

Berdasarkan temuan hasil penelitian dapat disimpulkan bahwa implementasi strategi reciprocal teaching berorientasi cooperative learning untuk meningkatkan hasil belajar pada materi pokok reaksi redoks di SMA Negeri 11 dapat terlaksana secara efektif yang didukung oleh aktivitas siswa, respon siswa yang positif, meningkatnya hasil belajar kognitif dan keterampilan sosial siswa.

\section{DAFTAR PUSTAKA}

Arends, R. I. 1997. Classroom Instructional and Management. USA: The McGraw-Hill Companies, Inc.

Borich, G. D. 1994. Observation Skills for Effective Teaching. USA: Macmillan Publishing Company.

BSNP. 2007. Permen Nomor 41 Tentang Standar Proses untuk Satuan Pendidikan Dasar dan Menengah. Jakarta: Depdiknas.

Budiningsih, A. 2005. Belajar dan Pembelajaran. Jakarta: PT Rineka Cipta.

Choo, T. O., Eng, T. K., \& Ahmad, N. 2011. "Effect of Reciprocal Teaching Strategies on Reading Comprehension". The Reading Matrix, 11(2), pp. 140-149.

Depdiknas. 2008a. Pengembangan Rencana Pelaksa-naan Pembelajaran (RPP). Jakarta: Direktorat Pembinaan SMA

Depdiknas. 2008b. Panduan Pengembangan Bahan Ajar. Jakarta: Direktorat Pembinaan SMA

Depdiknas. 2008c. Panduan Pengembangan Materi Pembelajaran. Jakarta: Direktorat Pembinaan SMA.

Fadholi. 2004. "Pengajaran Terbalik (Reciprocal Teaching) pada Pokok Bahasan Energi di MTsM 3 Sumberrejo Bojonegoro". Tesis Magister Pendidikan, Universitas Negeri Surabaya
Garderen, D. v. 2004. "Reciprocal Teaching As A Comprehension Strategy For Understanding Mathematical Word Problems, Focus On Inclusion". Reading \& Writing Quarterly, 20, pp. 225-229.

Grounlund, N. E. 1981. Measurement and Evaluation in Teaching. USA: Macmillan Publishing Co., Inc.

Nur, M., \& Wikandari, P. R. 2008. Pengajaran Berpusat kepada Siswa dan Pendekatan Konstruktivis dalam Pengajaran. (Edisi 5). Surabaya: Pusat Sains dan Matematika Sekolah UNESA.

Ofodu, G. O., \& Lawal, R. A. 2011. "Cooperative Instructional Strategies an Performance Levels of Students in Reading Comprehension". International Journal of Education Science, 3(2): 103-107.

Palincsar, A. S., \& Brown, A. L. 1984. "Reciprocal Teaching of Comprehension Fostering and Comprehension Monitoring Activities". Cognition and Insruction, 1984, I(2), pp. 117175.

Pandey, N., \& Kishore, K. 2003. "Effect of Cooperative Learning on Cognitve Achievement In Science". Journal of Science and Mathematics Education In S.E. Asia, 2(2), pp. 52-60.

PMPTK, Depdiknas. 2008. Strategi Pembelajaran MIPA. Jakarta: Dirjen PMPTK- Depdiknas.

Prabowo. 2011. Metodologi Penelitian (Sains dan Pendidikan Sains). Surabaya: Unesa University Press.

Purwanto, M. N. 2010. Psikologi Pendidikan. Bandung: PT Remaja Rosdakarya.

Qohar, A. 2009. "Pemahaman Matematis Siswa Sekolah Menengah Pertama pada Pembelajaran dengan Model Reciprocal Teaching". Prosiding Seminar Nasional Matematika dan Pendidikan Matematika FMIPA UNY.

Rusman. 2011. Model-model Pembelajaran, Mengembangkan Profesionalisme Guru. Jakarta: PT Raja Grafindo Persada.

Sadulloh, U. 2011. Pedagogik (Ilmu Mendidik). Bandung: Penerbit Alfabeta.

Sanjaya, W. 2009. Strategi Pembelajaran Berorientasi Standar Proses Pendidikan. Jakarta: Kencana.

Sisovic, D., \& Bojovic, S. 2001. "The Elaboration of The Salt Hidrolysis Concept by Cooperative Learning". Journal of Science Education; 2001; 2, 1; ProQuest Education Journals pg. 19.

Slavin, R. E. 1995. Cooperative Learning, Theory, Research, and Practice, Second Edition. Singapore: Allyn and Bacon.

Tastan, O., \& Boz, Y. 2009. "Effect of Cooperative Learning on Students' Understanding of Reaction Rate". Turkey: Cukurova University.

Trianto. 2013. Mendesain Model Pembelajaran InovatifProgresif: Konsep, Landasan, dan Implementasinya pada Kurikulum Tingkat Satuan Pendidikan (KTSP). Jakarta: Kencana Prenada Media Group.

Wilujeng, I. 1999. "Penerapan Pendekatan RT (Pengajaran Balik) dalam Pembelajaran Fisika (IPBA) SMU pada Pokok Bahasan Tektonik Lempeng". Tesis Magister Pendidikan, Universitas Negeri Surabaya.

Yamin, H. M. 2008. Paradigma Pendidikan Konstruktivistik, Implementasi KTSP \& UU No. 14 Tahun 2005 tentang Guru dan Dosen. Jakarta: Gaung Persada Press (GP Press). 